\title{
Bbítuary
}

\section{MONA LESLEY WORTH}

In our January issue we published a short annotation concerning the retirement of Miss Worth owing to ill health. It is with the greatest regret that we now have to record her death on May 8 last.

There must be many of our old friends and subscribers, especially overseas, who will remember her with gratitude and affection and will recall the work she did, not only for the Fellowship of Postgraduate Medicine, but for them personally. Ever since she succeeded her predecessor in 1931 to become full Secretary she devoted the whole of her time and energy to the work of the Fellowship; in the course of time she became, as we said in our January number, a power behind the throne. Much of the value of her work was due not merely to her innate sense of duty, but to the personal interest she took in the postgraduate students who came to interview her and the efforts she made to satisfy their individual needs. This did much to enhance the reputation of the Fellowship, both in this country and in the Dominions; it led, moreover, to the formation of many real and lasting friendships, both with our own teachers, and also with our students who kept in touch with her and would send her Christmas greetings from far distant lands. When the work of the Fellowship underwent an inevitable diminution at the close of the last war, and many of the hospitals on which it formerly depended for the arrangement of its postgraduate courses ceased to be available to us, the future of our association seemed at the time to be in the balance. It was then, more than ever, perhaps, that Miss Worth's love of the Fellowship showed itself, and our work might well have come to an end but for her determination to keep it going and her co-operation with her honorary officers, who depended so much on her knowledge and experience, and who knew that when they looked to her for encouragement they would never look in vain.

The disease which eventually caused her death was discovered over two years ago. Although it was realized then that no cure was possible, the treatment which she received at the Middlesex Hospital from time to time was effective,' not only in affording her great relief from the pain she suffered, but also in prolonging her life and in enabling her for a considerable time to continue her work and to render all possible assistance to the lady who was to suceed her as Secretary. During the last weeks of her illness she suffered extreme pain at times, but it was characteristic of her that at no time did she ever utter a word of resentment at her lot.

It is with the fullest realization of the debt which the Fellowship owes to her that we bid her our farewell.

Requiem aeternam dona ei, Domine, et lux perpetua luceat ei. 